\title{
Antral gastric elastofibroma diagnosed by unroof biopsy with endoscopic submucosal dissection technique
}
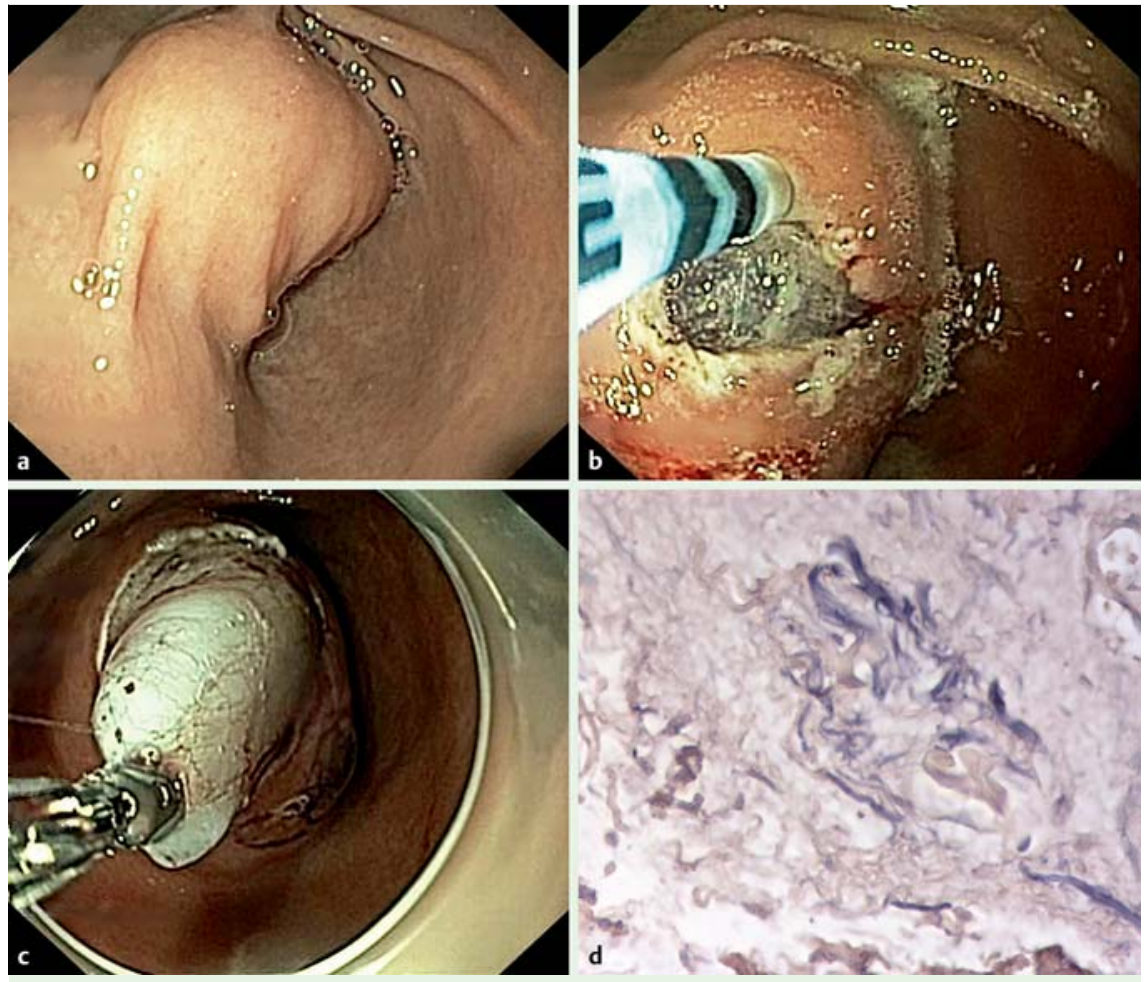

Fig. 1 a Endoscopic view of the antral mucosal bulge in a 52-year-old patient with a history of gastroesophageal reflux disease. $\mathbf{b}$ Unroofing of the lesion. $\mathbf{c}$ Endoscopic view during targeted biopsy with traction and enucleation of the elastofibroma. $\mathbf{d}$ Histological image showing scattered elastic fibers. Van Gieson rapid method, $\times 20$ magnification.

Elastofibroma is a rare pseudotumoral lesion of the soft tissues that is usually located in the subscapular region. Because of this common location, the lesion is often reported as elastofibroma dorsi. It presents as a deep-seated, firm mass, often several centimeters in diameter, that does not adhere to overlying skin. Visceral involvement, including involvement of the gastrointestinal tract, has been described very rarely [1 -3].

A 52-year-old patient with a history of gastroesophageal reflux disease (GERD) underwent esophagogastroduodenoscopy (EGD) at our institute. The endoscopy findings were negative for GERD-related lesions but showed a 3-cm mucosal bulge of the anterior wall of the gastric antrum, which was soft, mobile with peristalsis, and surrounded by normal mucosa ( $\bullet$ Fig.1a). Linear endoscopic ultrasound
(EUS) showed a 4-cm inhomogeneous, hypoechoic lesion in the submucosal layer, but fine-needle aspiration cytologic analysis was inadequate for a diagnosis.

In order to perform targeted biopsies, we planned to reach the lesion via unroof biopsy by using endoscopic submucosal dissection (ESD) techniques with a water jet dissecting knife (T-Type HybridKnife; Erbe Elektromedizin, Tübingen, Germany) $[4,5]$. A 2-cm mucosal incision was made, and a whitish submucosal soft tissue was exposed ( $\bullet$ Fig.1b). Intralesional water immersion EUS via a 20-MHz miniprobe (Olympus Medical Systems, Center Valley, Pennsylvania, USA) confirmed that the exposed whitish tissue corresponded to the submucosal lesion observed with linear EUS.

Biopsy specimens were taken directly inside the lesion, and surprisingly, the soft

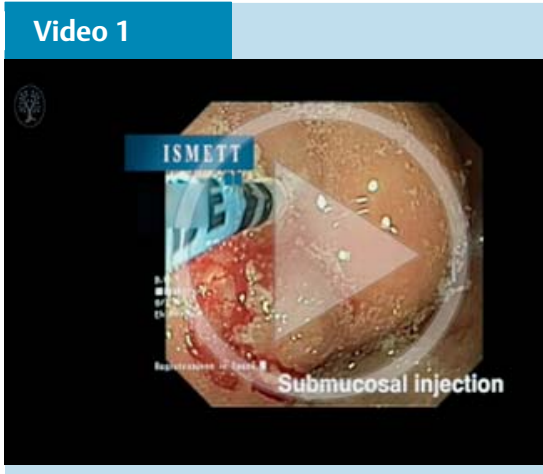

Antral gastric elastofibroma diagnosed by unroof biopsy with endoscopic submucosal dissection technique. ISMETT, Istituto Mediterraneo per i Trapianti e Terapie ad alta specializzazione; EUS, endoscopic ultrasound.

tissue was enucleated outside the incision during each biopsy, showing an unusual elastic response to traction ( Fig.1 c). Clip - band closure was done at the end of procedure.

Histology revealed acellular collagen fibers containing elastic serrated fibers, which were specifically stained with the van Gieson rapid method ( Fig.1d, - Video 1). The final diagnosis was a rare case of elastofibroma of the stomach, which did not require further treatment.

Endoscopy_UCTN_Code_CCL_1AB_2AD_3AB

Competing interests: None

Gabriele Curcio ${ }^{1}$, Dario Ligresti ${ }^{1}$, Antonino Granata ${ }^{1}$, Gaia Chiarello², llaria Tarantino ${ }^{1}$, Luca Barresi ${ }^{1}$, Mario Traina ${ }^{1}$

${ }^{1}$ Endoscopy Service, Department of Diagnostic and Therapeutic Services, IRCCS - ISMETT (Istituto Mediterraneo per i Trapianti e Terapie ad alta specializzazione), Palermo, Italy

2 Pathology Service, Department of Diagnostic and Therapeutic Services, IRCCS - ISMETT (Istituto Mediterraneo per i Trapianti e Terapie ad alta specializzazione), Palermo, Italy 


\section{References}

1 Saint-Paul MC, Musso S, Cardot-Leccia N et al. Elastofibroma of the stomach. Pathol Res Pract 2003; 199: 637-639

2 Enjoji M, Sumiyoshi K, Sueyoshi K. Elastofibromatous lesion of the stomach in a patient with elastofibroma dorsi. Am J Surg Pathol 1985; 9: 233-237

3 Sakatani T, Shomopr K, Adach $\mathrm{H}$ et al. Elastofibroma of the sigmoid colon. Pathol Res Pract 2000; 196: 205-207

4 Lee HL, Kwon OW, Lee KN et al. Endoscopic histologic diagnosis of gastric GI submucosal tumors via the endoscopic submucosal dissection technique. Gastrointest Endosc 2011; 74: 693-695
5 Binmoeller KF, Shah JN, Bhat YM et al. Suckligate-unroof-biopsy by using a detachable 20-mm loop for the diagnosis and therapy of small subepithelial tumors (with video). Gastrointest Endosc 2014; 79: 750-755

\section{Bibliography}

Dol http://dx.doi.org/

10.1055/s-0034-1392969

Endoscopy 2015; 47: E471-E472

(c) Georg Thieme Verlag KG

Stuttgart · New York

ISSN 0013-726X
Corresponding author

\section{Gabriele Curcio, MD}

Endoscopy Service

Department of Diagnostic and Therapeutic Services

IRCCS - ISMETT

Via Tricomi 5

90127 Palermo

Italy

Fax: +39-091-21-92-400

gcurcio@ismett.edu 